Tohoku J. exp. Med., 1982, 137, 349-360

\title{
The Variations of Estrogen Receptor, Progesterone Receptor, cAMP, ODG Activity and RNA Synthesis of Deciduomata in Pseudopregnant Rats
}

\author{
Hiroshi Hoshiai, Shigeki Uehara, Masakuni Suzuki \\ and Claude A. Villee* \\ Department of Obstetrics and Gynecology, Tohoku University \\ School of Medicine, Sendai 980 and * Department of Biological \\ Chemistry, Laboratory of Human Reproduction and \\ Reproductive Biology, Harvard Medical School, Boston, \\ Mass., USA
}

\begin{abstract}
Hoshiat, H., Unhara, S., Suzuki, M. and Villee, C.A. The Variations of Estrogen Receptor, Progesterone Receptor, cAMP, ODC Activity and RNA Synthesis of Deciduomata in Pseudopregnant Rats. Tohoku J. exp. Med., 1982, 137 (4), 349360 - The present study was done to define the conditions of implantation of fertilized ovum from serial day-to-day changes in the tissue weight of deciduomata in pseudopregnancy, estrogen receptor $(\mathrm{ER})$, progesterone receptor $(\mathrm{PR})$, cAMP content, RNA synthesizing capacity and ornithine decarboxylase activity (ODC). Pseudopregnancy was induced in Wistar rats in the estrus morning by vaginocervical stimulation. At the 4th day of pseudopregnancy deciduomata was induced by intraluminal instillation of olive oil with simultaneous oophorectomy and intramuscular injection of $20 \mathrm{mg}$ progesterone depot (the day of induction of decidualization was arbitrarily expressed as $D_{0}$ and the ensuing days, as $D_{1}, D_{2}$ and so on). The number of binding sites of ER and PR was estimated by exchange assay using dextran charcoal. cAMP content and RNA synthesizing capacity were determined by RIA and ${ }^{3} \mathrm{H}$-UTP uptake, respectively. ODC activity was measured by the method of Jänne and Williams-Ashman. Following the induction of deciduomata the uterus weight (unilateral) increased abruptly to 2-fold at $\mathrm{D}_{2}$ and approximately 30 -fold $(4.5 \mathrm{~g})$ at $\mathrm{D}_{8}$ and declined thereafter. ER diminished in a linear fashion from $2.77 \times 10^{-10} \mathrm{M}$ at $\mathrm{D}_{2}$ to $0.53 \times 10^{-10} \mathrm{M}$ at $\mathrm{D}_{7}$. On the other hand, PR was estimated $2.9 \times 10^{-10}$ at $\mathrm{D}_{2}, 2.5 \times 10^{-10} \mathrm{M}$ at $\mathrm{D}_{5}$ and decreased further at $\mathrm{D}_{6}$ and $\mathrm{D}_{7}$. cAMP was 77 nmoles/mg protein at $\mathrm{D}_{2}$ and decreased rapidly from $\mathrm{D}_{3}$ onward. RNA synthesizing capacity declined in a linear fashion from $D_{3}$ to $1 / 2$ at $D_{5}$ and $1 / 3$ at $D_{7}$. ODC was found $1.7 C_{2}$ nmoles/mg protein at $D_{2}$, decreased at $D_{3}$ and $D_{4}$, but remained nearly the same at $\mathrm{D}_{4}$ and $\mathrm{D}_{5}$ deciduomata; ODC activity; pseudopregnancy; hormone receptor; rats
\end{abstract}

The decidual cells in the pseudopregnant rat uterus undergo many of the structural and functional changes which were exhibited by endometrial cells in normal pregnancy. Thus the decidual reaction in pseudopregnancy has been studied as a model of implantation process. The proliferation and differentiation

Received for publication, October 15, 1981. 
of stromal fibroblasts into decidual cells require both estrogen and progestin in addition to some kind of trauma to the endometrium. The trauma may be a needle scratch, a thread tied through the endometrium, or the intraluminal instillation of olive oil. The decidual tissue of pseudopregnant rats contains high-affinity, low-capacity receptor proteins specific for estrogens (Talley et al. 1977) and other receptor proteins for progestin (Armstrong et al. 1977). The binding of steroid to the receptor proteins is believed to be an obligatory first step in the action of steroid hormones. Estrogen receptors have been demonstrated in the cytosol (Mester et al. 1974) and in the nucleus (Martel and Psychoyos 1976) of the endometrium during pregnancy.

Ornithine decarboxylase (ODC, L-ornithine carboxylase, EC 4.1.1.17) undergoes an increase in activity as feature of the early response of many target tissues to their respective hormones.

The ornithine decarboxylase $(\mathrm{ODC})$ activity of the prostate is stimulated by testosterone (Pegg et al. 1970), that of the rat uterus or chick oviduct is stimulated by estradiol (Cohen et al. 1970; Kaye et al. 1971; Villee and Loring 1975), that of the liver is stimulated by growth hormone (Jänne and Raina 1969), and that of the adrenal is stimulated by adrenocorticotropic hormone (Richman et al. 1973). Ovarian ODC activity rises sharply during the pre-ovulatory surge of luteinizing hormone (Kobayashi et al. 1971), and the rise of activity can be prevented by the injection of anti-LH before proestrus. Ovarian ODC increases sharply within an hour after the administration of $\mathrm{LH}$ and this appears to reflect the de novo synthesis of the enzyme, for the rise is prevented by actinomycin D or cycloheximide (Kaye et al. 1973). The ODC activity of the immature rat testis is stimulated by luteinizing hormone, follicle-stimulating hormone or cyclic adenosine monophosphate (cAMP) (Reddy and Villee 1975; Villee and Loring 1978). Increased ODC activity in response to normal stimulation has been demonstrated in fibroblasts (Haselbacher and Humbel 1976), granulosa cells (Osterman and Hammon 1977), hepatocytes (Klingensmith et al. 1980), and kidney cells (Villee 1980) in culture. The activity of the enzyme is increased in essentially all rapidly growing cells such as tumor cells, embryonic tissues and cells following viral infection. It seemed to be of interest to know the relationship between estrogen receptor, progesterone receptor, cAMP, RNA synthesis and ODC activity of decidual tissue from different stages of pseudopregnancy.

\section{Materials and Methods}

Animals. Virgin Sprague-Dowley rats (Charles River, Wilmington, MA) weighing 250 to $300 \mathrm{~g}$ were maintained under a program of $14 \mathrm{hr}$ of darkness. Pseudopregnancy was induced in regularly cycling rats in the morning of estrus by vagino-cervical vibration for 1 min (DeFeo 1966). The day of estrus was designated as day zero of pseudopregnancy. Uterine decidualization was induced by intraluminal instillation of $50 \mu \mathrm{l}$ of olive oil through the ovarian end of the uterine horn in the afternoon of day 4 of pseudopregnancy. The rats were ovariectomized and injected subcutaneously with $20 \mathrm{mg}$ of Depo-Provera. Therefore day 4 of pseudopregnancy was designated as day zero of decidualization. On days 2-11 after the instillation of oil, both the decidualized horn and the untreated, 
contralateral horn were removed and weighed. The untreated horns weighed approximately $0.15 \mathrm{~g}$, whereas the weights of the decidualized horns ranged from 0.6 (day 2) to $4.5 \mathrm{~g}$ (day 8). Decidualized horns were slit open and the deciduomata were removed from the myometrium by gentle scraping with a glass slide. All tissue samples were placed immediately in 0.9 $\%$ saline on ice and further treatment was performed at $0-4^{\circ} \mathrm{C}$.

Cytosol preparation and Scatchard analysis. Tissues were minced and homogenized with glass-glass conical grinders in 20 volumes TED-BSA buffer (0.01 M Tris-HCl, $\mathrm{pH} 7.5$; $1.5 \mathrm{mM}$ sodium EDTA; $1 \mathrm{mM}$ dithiothreitol; $0.1 \%$ bovine serum albumin containing $30 \%$ $(\mathrm{wt} / \mathrm{v})$ glycerol. Tissue homogenates were centrifuged for $1 \mathrm{hr}$ at $105,000 \times \mathrm{g}$ and cytosols were treated $15 \mathrm{~min}$ with dextran coated charcoal (DCC). The cytosol preparations were diluted to appropriate protein concentrations with TED-BSA buffer and incubated with $10-30 \times 10^{-11} \mathrm{M}\left(3,4,6,7{ }^{3} \mathrm{H}\right)-17 \beta$-estradiol $(\mathrm{SA} 85-105 \mathrm{Ci} / \mathrm{mmole})$ or $10-40 \times 10^{-10} \mathrm{M}(1,2,6,7$ ${ }^{3} \mathrm{H}$ )-progesterone (SA $104 \mathrm{Ci} / \mathrm{mmole}$ ). To correct for non-specific binding, other samples of the cytosol preparation containing labeled hormone and a hundred-fold excess of unlabeled hormone were incubated. After incubation to equilibrium (23 hr), unbound steroid was removed by DCC treatment for $15 \mathrm{~min}$ as cited above. The amount of labeled hormone bound to the cytosol receptor was measured and the data were expressed according to Scatchard (1949).

Ornithine decarboxylase assay. ODC activity was assayed as described by Jänne and Williams-Ashman (1971). Tissues were homogenized in five volumes of buffer containing 25 $\mathrm{mM}$ Tris-HCl, $\mathrm{pH} 7.4,0.1 \mathrm{mM}$ sodium EDTA and $5 \mathrm{mM}$ dithiothreitol. The homogenate was centrifuged at $38,000 \times \mathrm{g}$ for $10 \mathrm{~min}$ at $4^{\circ} \mathrm{C}$ and the supernatant fraction was assayed

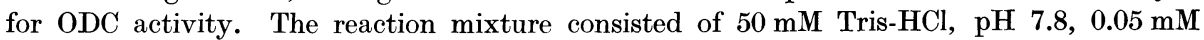
pyridoxal phosphate, $5 \mathrm{mM}$ dithiothreitol, $0.5 \mathrm{mM}$ DL-ornithine labeled with ${ }^{14} \mathrm{C}$ in the carboxyl group (NEN-469, SA 30 to $55 \mathrm{Ci} / \mathrm{mM}$ ) and 0.1 to $0.4 \mathrm{ml}$ of enzyme preparation in a total volume of $0.5 \mathrm{ml}$. The incubations were carried out at $37^{\circ} \mathrm{C}$ for $1 \mathrm{hr}$ with shaking in test tubes containing polypropylene center wells suspended from the rubber stopper. The center wells contained $0.2 \mathrm{ml}$ hyamine hydroxylase to trap $\mathrm{CO}_{2}$. After $1 \mathrm{hr}$ of incubation $0.5 \mathrm{ml}$ of $1 \mathrm{~N} \mathrm{H}_{2} \mathrm{SO}_{4}$ was added to the reaction mixture to ensure complete release of the carbon dioxide. After a further $30 \mathrm{~min}$ incubation the center wells were removed and transferred to scintillation vials containing $4 \%$ Liquifluor in toluene and counted in a Packard scintillation spectrometer with an efficiency for ${ }^{14} \mathrm{C}$ of $84 \%$. All assays were done at three different levels of supernatant and in duplicate at each level. This was done to ensure that the ODC activity measured was a linear fraction of the amount of supernatant added.

Cyclic adenosine monophosphate assays. Tissues were placed in $0.5 \mathrm{ml}$ of $\mathrm{H}_{2} \mathrm{O}$ and boiled for $3 \mathrm{~min}$, then cooled, homogenized and centrifuged. The supernatant was transferred to plastic tubes and frozen at $-70^{\circ} \mathrm{C}$ until assayed. The supernatant fraction was assayed by a double antibody radioimmunoassay method according to Steiner et al. (1972) using a kit purchased from Collaborative Research Inc., Waltham, MA.

Isolation of decidual nuclei. Decidual tissues removed from uterine horns were homogenized in 10 volumes of $0.25 \mathrm{M}$ sucrose containing $10 \mathrm{mM} \mathrm{MgCl}_{2}$, and filtered through four layers of cheese cloth. The homogenates were centrifuged at $600 \times \mathrm{g}$ for $10 \mathrm{~min}$. The pellets were resuspended in 10 volumes of $2.2 \mathrm{M}$ sucrose and homogenized for 10 strokes in a Teflon-glass homogenizer. The homogenates were centrifuged at $48,000 \times \mathrm{g}$ for $60 \mathrm{~min}$ at $4^{\circ} \mathrm{C}$. Finally the pellets were resuspended in $100 \mathrm{mM}$ Tris-HCl, $\mathrm{pH} 7.5$ to assay their ability to synthesize RNA.

$R N A$ synthesis by decidual nuclei. The ability of isolated nuclei to incorporate ${ }^{3} \mathrm{H}$ uridine triphosphate (UTP) (NEN, 37.5 Ci/mM) into RNA was assayed in a system (total volume $0.5 \mathrm{ml}$ ) containing $0.1 \mathrm{M}$ Tris- $\mathrm{HCl}, \mathrm{pH} 7.5,2 \mathrm{mM} \mathrm{MnCl}_{2}, 3 \mathrm{mM} \mathrm{MgCl}, 1.3 \mathrm{mM} \mathrm{NaF}$, $0.5 \mathrm{mM}$ ATP, $0.5 \mathrm{mM}$ CTP, $0.5 \mathrm{mM}$ GTP, $2 \mathrm{mM}$ spermidine, $0.27 \mathrm{mM}\left(5,6{ }^{-} \mathrm{H}\right)$-UTP and 0.2 $\mathrm{ml}$ of resuspended nuclei (100 to $200 \mu \mathrm{g}$ DNA). Following the addition of nuclei, the reaction mixture was incubated at $37^{\circ} \mathrm{C}$ with shaking for $30 \mathrm{~min}$ (Hoshiai et al. 1981). Samples were then plunged into ice and two $0.05 \mathrm{ml}$ aliquots were pipetted on the Whatman $\$ 1$ filter paper discs (diameter $2.3 \mathrm{~cm}$ ) which were immediately dropped into an ice-cold 
solution of $10 \%$ trichloroacetic acid (TCA) containing $1 \%(\mathrm{w} / \mathrm{v})$ sodium pyrophosphate. After $15 \mathrm{~min}$, the discs were washed three times in $5 \%$ TCA containing $0.5 \%$ sodium pyrophosphate, two times in $95 \%$ ethanol, once in ethanol: ether $(1: 1)$ and two times in ether and air dried. The dried discs were then placed in $10 \mathrm{ml}$ of toluene containing $4 \%$ Liquifluor. Radioactivity was measured in an Packard scintillation spectrometer with an efficiency for ${ }^{3} \mathrm{H}$ of $30 \%$.

DNA and protein determination. DNA was determined by the method of Burton (1956), using denatured calf thymus DNA as standard. Protein concentrations were measured by the method of Lowry et al. (1951), using bovine serum albumin as standard.

Chemicals. ATP, CTP, GTP, pyridoxal phosphate, and dithiothreitol were purchased from Sigma, St Louis, MO. Spermidine trihydrochloride was purchased from Calbiochem., Sandiego, CA. $\left(3,4,6,7-{ }^{3} \mathrm{H}\right)-17 \beta$-estradiol, $\left(1,2,6,7-{ }^{3} \mathrm{H}\right)$ progesterone, DL-ornithine monohydrochloride $\left(1-{ }^{14} \mathrm{C}\right), 5,6-{ }^{3} \mathrm{H}-\mathrm{UTP}$, and Liquifluor were purchased from New England Nuclear, Boston, MA.

\section{Results}

Changes in uterine horn weight after induction of decidualization by uterine oil injection

When stimulated by the injection of oil (day 4 of pseudopregnancy), the rat's uterine horn increased in weight to approximately 30 times that of untreated horn by the seventh to eighth day of decidualization (Fig. 1). The increase in weight was due to the induction, proliferation, and growth of the deciduomata from transformed fibroblasts of the endometrium, as well as to hypertrophy of the myometrial cells. By the eighth day the decidual mass was reduced and the onset of necrosis is apparent.

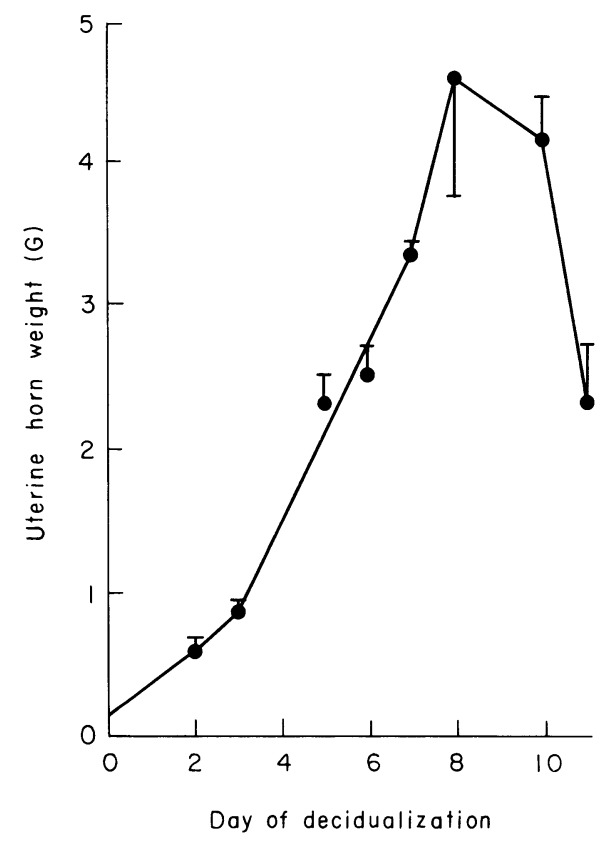

Fig. 1. Change in uterine horn weight after induction of decidualization by uterine oil injection. Values expressed are the mean \pm s.D. for 3-8 measurements. 
Estrogen receptors in decidual tissue

On day 2 of decidualization the concentrations of high-affinity estrogen receptor in the untreated and decidualized uterine horns were similar. By day 3 the decidual tissue comprised approximately one-half of the mass of the horn. The concentration of estrogen receptor in the cytosols of decidual tissue on day 3 was $1.75 \pm 0.20 \times 10^{-10} \mathrm{M}$. By day 7 of decidualization the concentration of highaffinity receptor in the deciduomata had decreased to $0.53 \pm 0.10^{-10} \mathrm{M}$. By day 5 of decidualization the level of decidual estrogen receptor was reduced despite the fact that the weight of the decidualized uterine horns continued to increase until day 8 (Fig. 2). The number of estrogen receptors in the deciduomata had decreased and continued to drop despite continued growth of the tissues until day 7. The decidual tissue began to regress on day 7 and necrotic changes were extensive by day 10 .

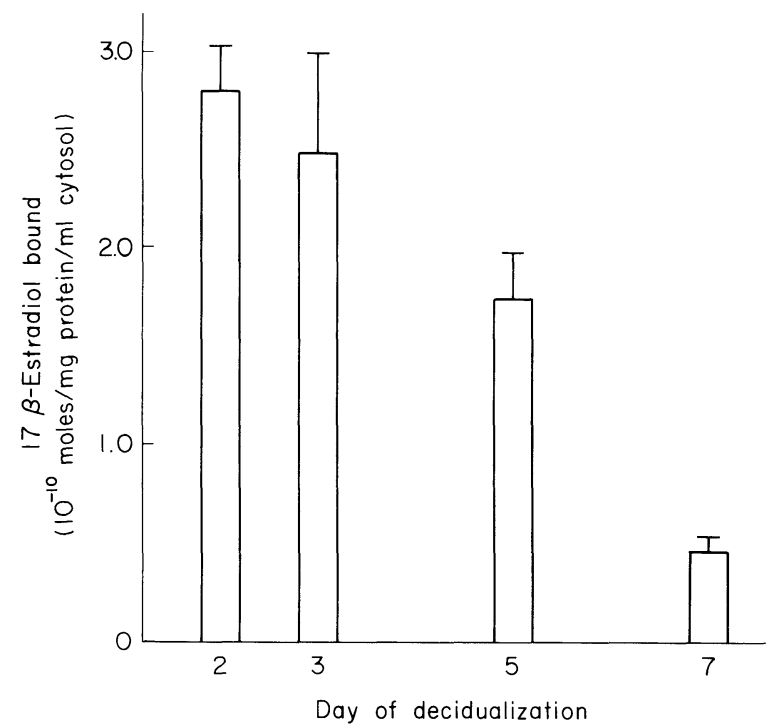

Fig. 2. Change in concentration of estradiol binding sites (expressed for $1 \mathrm{mg}$ protein/ml cytosol) as a function of decidualization. Mean and s.E.

\section{Progesterone receptors in decidual tissue}

The affinity constants for progesterone binding were $10^{-9} \mathrm{M}$ in the uteri of estrus and proestrus rats, in the untreated horns on days 3 and 6 of decidualization, and decidualized horns (Armstrong et al. 1977). The average concentrations of progesterone receptor sites in the cytosol of deciduomata on days 3 and 5 were $3.37 \times$ $10^{-10}$, and $2.49 \times 10^{-10} \mathrm{M}$, respectively. After the fifth day of decidualization, the concentration of progesterone receptor sites decreased linearly and on day 7 the receptor sites were $1.63 \times 10^{-10} \mathrm{M}$, a level approximately one-half that of day 3 or 5 (Fig. 3). This change in receptor concentration in deciduomata on days 5 to 7 was statistically significant $(p<0.01)$. 


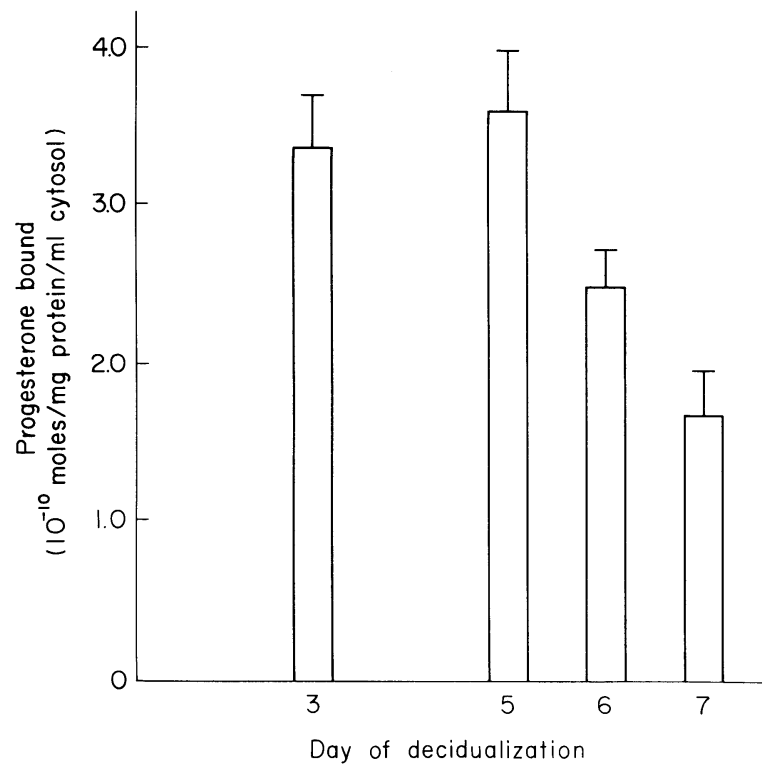

Fig. 3. Change in concentration of progesterone binding sites (expressed for $1 \mathrm{mg}$ protein/ $\mathrm{ml}$ cytosol) as a function of decidualization. Mean and s.E.

\section{cAMP content in deciduomata}

The amount of cAMP in decidual tissues of pseudopregnant rats with or without estradiol injections was compared in a similar series of experiments (Fig. 4). The injection of neither 1 nor $2 \mu \mathrm{g}$ of estradiol had any effect on the cAMP content of decidual tissues in 2, 3, 4, or 5-day decidualized rats. Although there have been some reports that estradiol affected the activity of adenyl cyclase and the concentration of cAMP in certain tissues, we could find no evidence for such an effect in the rat decidua.

\section{Ornithine decarboxylase activity of deciduomata}

On day 2 of decidualization ODC activity was 1.70 nmoles $\mathrm{CO}_{2} / \mathrm{mg}$ protein. On day 3 that was 0.79 nmoles $\mathrm{CO}_{2} / \mathrm{mg}$ protein, which was approximately one-half of that on day 2. After day 4 of decidualization, ODC activity decreased linearly; the change was similar to that of estrogen receptor (Fig. 5). Moreover, the injection of $2 \mu \mathrm{g}$ of estradiol substantially increased ODC activity in the decidua of rats two to three days after decidualization. Injected estradiol had a lesser effect on decidua four days after decidualization and had no effect after five days. The injection of $1 \mu \mathrm{g}$ of estradiol in a similar series had no effect on ODC activity in decidua of rats on any day after decidualization (Table 1). The effectiveness of estradiol two to three days after decidualization and the disappearance of the effect in five-day decidualized rats could be correlated very nicely with the decreased content of estrogen receptors in decidual tissue on day 5 of decidualization. 


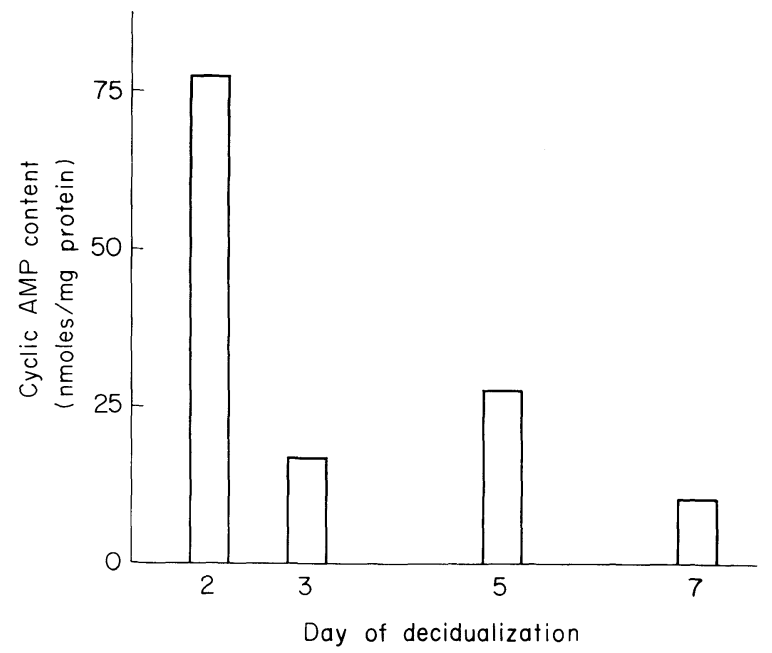

Fig. 4. Change in content of cyclic AMP in deciduomata. Values are means of 3 experiments.

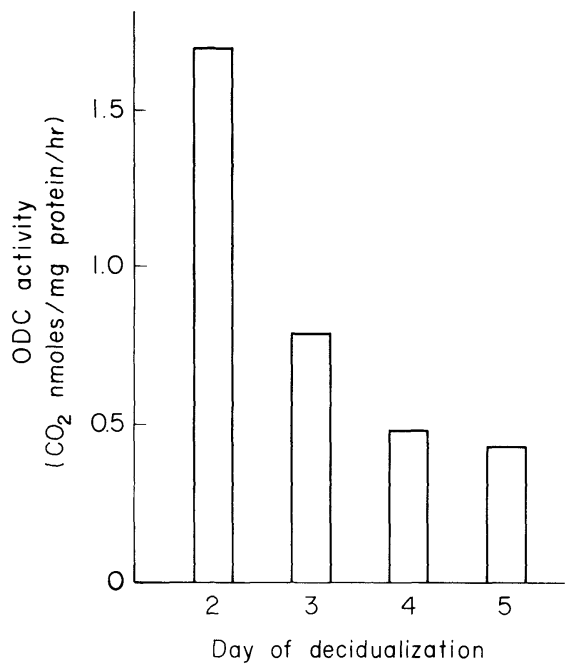

Fig. 5. Ornithine decarboxylase activity during decidual tissue development. Values are means of 3 experiments.

The ability of RNA synthesis by decidual nuclei

${ }^{3} \mathrm{H}$-UTP incorporation to RNA by decidual nuclei on day 3 of decidualization was $398 \mathrm{dpm} / \mu \mathrm{g}$ DNA. After the 3rd day of decidualization, the incorporation of ${ }^{3} \mathrm{H}$-UTP into RNA decreased linearly. On day 5 and day 7 of decidualization, ${ }^{3} \mathrm{H}$-UTP incorporation into RNA was $334 \mathrm{dpm} / \mu \mathrm{g}$ DNA and $180 \mathrm{dpm} / \mu \mathrm{g} \mathrm{DNA}$, respectively (Fig. 6). 
TABLE 1. Effect of estrogen injected in vivo on ornithine decarboxylase activity in decidual tissue of the pseudopregnant rat

\begin{tabular}{cccc}
$\begin{array}{c}\text { Day of } \\
\text { decidualization }\end{array}$ & Control & \multicolumn{2}{c}{$\begin{array}{c}\text { Injection of } \\
17 \beta \text {-estradiol }\end{array}$} \\
\hline 2 & & $1 \mu \mathrm{g}$ & $2 \mu \mathrm{g}$ \\
3 & 1.70 & 1.54 & 2.88 \\
4 & 0.79 & 0.56 & 2.67 \\
5 & 0.48 & 0.46 & 0.75 \\
& 0.43 & 0.44 & 0.41
\end{tabular}

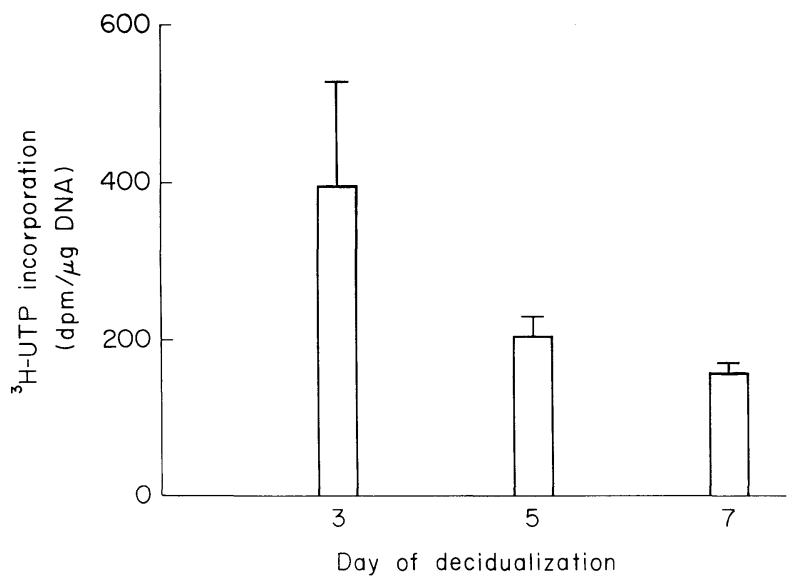

Fig. 6. The ability of RNA synthesis by decidual nuclei. Mean and s.E.

\section{Discussion}

A priming dose of estrogen, or estrogen secreted at proestrus, followed by an increase in the concentration of circulating progesterone is required for decidualization (Nelson and Pfiffner 1930; Yochim and DeFeo 1972). Progesterone plays a major role in regulating the sensitivity of the uterus to decidualization, but estrogen modulates the changes that occur (Psychoyos 1973). Maximal proliferation of the stromal fibroblasts transformed to deciduomata in the rat requires a continued low level of estrogen along with an elevated level of progesterone (Yochim and DeFeo 1972). Administration of high estrogen doses, comparable to those secreted in estrus, results in a reduction in the mass of decidual tissue produced (Velardo and Hisaw 1951; Finn and Martin 1972). Neither the biochemical mechanism triggering decidualization nor the mechanism leading to decidual regression is known.

The action of steroids is generally believed to be initiated by the formation of a steroid receptor-complex and the movement of the receptor-ligand complex into the nucleus. High affinity estrogen receptors were proved by Talley et al. (1977) 
to be present in deciduomata in pseudopregnant rats. Estrogen receptor in deciduomata with an affinity constant of $10^{10} \mathrm{M}^{-1}$ is identical with that of the receptor in non-gravid uterus of cycling rats (Toft and Gorski 1966). The number of high-affinity binding sites as measured by Scatchard analysis is the same during the early stages of decidualization as in the uteri of rats ovariectomized at estrus. The concentration of cytosol binding sites measured during decidualization of pseudopregnancy is probably greater than $90 \%$ of the total receptor concentration. It has been estimated from binding measurements with uterine cell suspensions that at estrus, no more than $10 \%$ of high-affinity estradiol receptors would be saturated with circulating endogenous hormone (Williams and Gorski 1974). Since circulating estradiol during the decidualization period dose not exceed estrus concentrations, our finding that the concentrations of estrogen binding sites in cytosols of untreated uterine horns on days 2,3 and 7 of decidualization are similar to those of uteri from estrus rats after ovariectomy is further support for this assumption (Talley et al. 1977). By the 5th day of decidualization the number of receptors in the deciduomata had decreased and continued to drop despite continued growth of the tissue until day 7 .

Maximal growth of the deciduomata in the rat requires the presence of continued low level of estrogen in addition to high level of progesterone (Yochim and DeFeo 1972). When elevated progesterone levels are maintained for a prolonged period the deciduomata achieve their maximum growth potential and then degenerated in spite of the continued presence of the hormone (Finn and Porter 1975). These findings suggest that factors other than the circulating levels of steroid hormones have a regulatory role in decidual regression. The concentrations of progesterone receptors in cytosol of deciduomata from days 3 and 5 are similar to those in uterine cytosols of estrus rats and in the contralateral untreated uterine horn at days 3 and 6 of decidualization. The receptor site concentration in decidual cytosols undergoes a linear decrease between days 5 and 7 of decidualization. This decrease is preceded by a change in estrogen receptor concentration which decreases linearly from day 2 until day 7 of decidualization (Talley et al. 1977). These decreases appear to be independent of changes in the circulating levels of estrogen and progesterone which remain relatively constant during this period (Yoshinaga et al. 1969; Pepe and Rothchild 1974). These observations suggest that factors other than the circulating levels of estrogen and progesterone are involved in the regulation of these receptor concentrations during decidual development. The concentration of progesterone receptor sites in the deciduomata remains constant from days 3 to 5 of decidualization. Since there is rapid tissue growth during this period, this finding indicates parallel rates of synthesis for the progesterone receptor and total soluble protein through day 5 of decidualization. After day 5 of decidualization there is a linear decrease in progesterone receptor site concentration (expressed per mg soluble protein) even though tissue growth continues through day 7. The cessation of receptor synthesis and subsequent dilution of the receptor by continued synthesis of total soluble protein could account for this decrease. 
ODC activity is increased as a feature of the early response of many target tissues to their respective hormones and also increased in essentially all rapidly growing tissues and cells. The present experiments demonstrated that decidual tissue responds to estradiol administered to pseudopregnant rats in vivo with an increase in ODC activity if the estrogen is administered to rats on two, three or four days after decidualization. The ODC activity in the decidual tissue reaches a peak $4 \mathrm{hr}$ after the administration of estradiol; thus, time course of the response in decidual tissue is similar to that in the uterus of the non-pregnant rat (Hoshiai et al. 1981). By day 5 of decidualization the level of ODC activity was reduced despite the fact that the weight of the decidualized horns continued to increase until day 8.

The nuclei of 3,5 or 7-day decidual tissues are active in synthesizing RNA and the rate of synthesis is a function of the amount of DNA present in the reaction tube. The rate of RNA synthesis decreases as decidualization progresses from day 3 or 5 , but not day 7 when the deciduomata are still growing.

These results demonstrated the discrepancy between the increase of the weight of deciduomata and the levels of estrogen receptor, progesterone receptor, ODC activity and RNA synthesis.

\section{References}

1) Armstrong, E.G., Jr., Tobert, J.A., Talley, D.J. \& Villee, C.A. (1977) Changes in progesterone receptor levels during deciduomata development in the pseudopregnant rat. Endocrinology, 101, 1545-1551.

2) Burton, K. (1956) A study of the conditions and mechanism of the diphenylamine reaction for the colorimetric estimation of deoxyribonucleic acid. Biochem. J., 62, $315-323$.

3) Cohen, S., O'Malley, B.W. \& Stansy, M. (1970) Estrogenic induction of ornithine decarboxylase in vivo and in vitro. Science, 170, 336-338.

4) DeFeo, V.J. (1966) Vaginal-cervical vibration a simple and effective method for the induction of pseudopregnancy in the rat. Endocrinology, 79, 440-442.

5) Finn, C.A. \& Martin, L. (1972) Endocrine control of the timing of endometrial sensitivity to a decidual stimulus. Biol. Reprod., 7, 82.

6) Finn, C.A. \& Porter, D.G. (1975) The decidual cell reaction. In: The Uterus, Elek Science Publ., London, p. 81.

7) Haselbacher, G.F. \& Humbel, R.F. (1976) Stimulation of ornithine decarboxylase activity in chick fibroblasts by non-suppressive insuline-like activity (NSILA), insulin and serum. Endocrinology, 106, 239-245.

8) Hoshiai, H., Lin, Y.C., Loring, J.M., Perel-le, B.A. \& Villee, C.A. (1981) Ornithine decarboxylase activity and polyamine content of the placenta and decidual tissue in the rat. Placenta, 2, 105-116.

9) Jänne, J. \& Raina, A. (1969) On the stimulation of ornithine decarboxylase and RNA polymerase activity in the rat liver after treatment with growth hormone. Biochem. biophys. Acta, 174, 769-772.

10) Jänne, J. \& Williams-Ashman, H.G. (1971) On the purification of L-ornithine decarboxylase and effect of thiol compounds on the enzyme. J. biol. Chem., 246, 1725-1732.

11) Kaye, A.M., Icekson, I. \& Liner, H.R. (1971) Stimulation by estrogens of ornithine and S-adenosyl methionine decarboxylase in the immature rat uterus. Biochem. biophys. Acta, 252, 150-159. 
12) Kaye, A.M., Icekson, I., Lamprecht, S.A., Gruss, R., Tsafriri, A. \& Linder, H.R. (1973) Stimulation of ornithine decarboxylase activity by luteinizing hormone in immature and adult rat ovaries. Biochemistry, 2, 3072-3076.

13) Klingensmith, M.R., Freifeld, A.F., Pegg, A.E. \& Jefferson, L.S. (1980) Effect of growth hormone and glucagon on ornithine decarboxylase activity and adenosine monophosphate levels in isolated rat hepatocytes. Endocrinology, 106, 125-132.

14) Kobayashi, Y., Kupelian, J. \& Maudsley, D.V. (1971) Ornithine decarboxylase stimulation in rat ovary by Juteinizing hormone. Science, 172, 379-380.

15) Lowry, O.H., Rosebrough, N.J., Farr, A.L. \& Randall, R.J. (1951) Protein mesurement with the Folin phenol reagent. J. biol. Chem., 193, 265-275.

16) Martel, D. \& Psychoyos, A. (1976) Endometrial content of nuclear estrogen receptor and reseptivity for ovoimplantation in the rat. Endocrinology, 99, 470-475.

17) Mester, I., Martel, D., Psychoyos, A. \& Baulieu, E.E. (1974) Hormonal control of estrogen receptor in uterus and receptivity for ovoimplantation in the rat. Nature (Lond.), 250, 776.

18) Nelson, W.O. \& Pfiffner, J.J. (1930) Experimental production of deciduomata in rat by extract of corpus luteum. Proc. Soc. exp. Biol. Med., 27, 863.

19) Osterman, J. \& Hammon, J.M. (1977) FSH and LH stimulation of ornithine decarboxylase activity studies with porcine granulosa cells in vitro. Endocrinology, 101, 1335-1338.

20) Pegg, A.E., Lockwood, D.H. \& Williams-Ashman, H.G. (1970) Concentrations of putrescine and polyamines and their enzymic synthesis during androgen-induced prostatic growth. Biochem. J., 117, 17-31.

21) Pepe, G.J. \& Rothchild, I. (1974) A comparative study of serum progesterone levels in pregnancy and in various types of pseudopregnancy in the rat. Endocrinology, 95, 275-279.

22) Psychoyos, A. (1973) Hormonal control of ovoimplantation. Vitamine Horm., 31, 201.

23) Reddy, P.R.K. \& Villee, C.A. (1975) Stimulation of ornithine decarboxylase activity by gonadotropin hormones and cyclic AMP in the testis of immature rats. Biochem. biophys. Res. Common., 65, 1350-1753.

24) Richman, R., Dobbins, C., Voina, S., Underwood, L., Mahaffee, D., Gitelman, H.J., VanWyk, J. \& Ney, R.L. (1973) Regulation of adrenal ornithine decarboxylase by adenocorticotropic hormone and cyclic AMP. J. clin. invest., 52, 2007-2015.

25) Scatchard, G. (1949) The attraction of proteins for small molecules and ions. Ann. N.Y. Acad. Sci., 51, 660.

26) Steiner, A.L., Parker, C.W. \& Kepnis, D.M. (1972) Radioimmunoassay for cyclic nucleotides. I. Preparations of antibodies and iodinated cyclic nucleotides. $J$. biol. Chem., 247, 1106-1113.

27) Talley, D.J., Tobert, J.A., Armstrong, E.G., Jr. \& Villee, C.A. (1977) Changes in estrogen receptor levels during deciduomata development in the pseudo-pregnant rat. Endocrinology, 101, 1538-1544.

28) Toft, D. \& Gorski, J. (1966) A receptor molecule for estrogens: isolation from the rat uterus and preliminary characterization. Proc. nat. Acad. Sci. USA, 55, 1974.

29) Velardo, J.T. \& Hisaw, F.L. (1951) Quantitative inhibition of progesterone by estrogens in development of deciduomata. Endocrinology, 49, 530.

30) Villee, C.A. (1980) Hormonal control of the release of steroid in m-RNA for ornithine decarboxylase. In: The Role of RNA in Development and Reproduction, edited by M.C. Niu, Peking, China. Academica Sinica.

31) Villee, C.A. \& Loring, J.M. (1975) Estrogenic control of uterine enzymes. Advanc. in Enzyme Regulation, 13, 137-150.

32) Villee, C.A. \& Loring, J.M. (1978) Effects of FSH and LH on RNA synthesis in the testis: role of ornithine decarboxylase. In: Structure and Function of the Gonadotropins, edited by K.W. Mckerns, Plenum Press, New York-London, pp. 295313. 
33) Williams, D. \& Gorski, J. (1974) Equilibrium binding of estradiol by uterine cell suspensions and whole uteri in vitro. Biochemistry, 13, 5537.

34) Yochim, J.M. \& DeFeo, V.J. (1972) Control of decidual growth in the rat by steroid hormones of the ovary. Endocrinology, 71, 134-142.

35) Yoshinaga, K., Hawkins, R.A. \& Stocker, J.F. (1969) Estrogen secretion by the rat ovary during the estrus cycle and pregnancy. Endocrinology, 85, 103-112. 